\title{
Measurement and assessment of workers' physical activity and sedentary behavior
}

\author{
Noritoshi Fukushima ", Shiho Amagasa, Masaki Machida, Hiroyuki Kikuchi and Shigeru Inoue \\ 東京医科大学公衆衛生学分野， ₹160-8402 東京都新宿区新宿6-1-1 (Department of Preventive Medicine and Public \\ Health, Tokyo Medical University, 6-1-1 Shinjuku, Shinjuku-ku, Tokyo 160-8402, Japan)
}

Received: June 30, 2020 / Accepted: July 17, 2020

\begin{abstract}
Evidence is growing on adverse health outcomes associated with less physical activity (PA) and more sedentary behavior (SB). As most workers generally spend approximately one-third of the day at work, measuring the amount of occupational PA/SB time would contribute to understanding the health risks of physical inactivity and SB among workers. In this review article, we describe the amount of time spent in different intensities of activity (moderateto-vigorous PA [MVPA]; light PA [LPA]; and SB), on work and non-work days, while at work and outside working hours among workers. The review used objective measurements made by an accelerometer and showed the proportion of MVPA that office workers engaged in on work and non-work days accounted for $3-5 \%$ and $2-4 \%$ of accelerometer wear time, respectively. Moreover, office workers spent more time in SB and less time in LPA on work days than nonwork days (SB, $66-76 \%$ vs. $60-69 \%$; LPA, $20-28 \%$ vs. $23-36 \%$ ). Especially on work days, office workers spent the greatest proportion of the day in SB during working hours (71-82\%), compared with that outside working hours (63-67\%). The proportion of MVPA accounted for 2-5\% during working hours and 3-7\% outside working hours. In addition, there were considerable differences in the proportions of LPA and SB between white-collar and blue-collar workers during working hours (SB, 73 vs. $55 \%$; LPA; 22 vs. $40 \%$ ), whereas the MVPA time was similar (5 vs. $5 \%$ ). Some occupational exposure to unfavorable $\mathrm{PA} / \mathrm{SB}$ at work might be unavoidable; however, inadequate PA/SB during working hours should be corrected.
\end{abstract}

Jpn J Phys Fitness Sports Med, 69(6): 447-455 (2020)

Keywords : physical activity, sedentary behavior, workers, questionnaire

はじめに

多くの労働者は一日の㧍よそ 3 分の 1 以上の時間を職 場で過ごしている1)。その職場環境に目を向ければ今日 の技術革新に伴い機械化・自動化が進み, 過去50年間一 貫して体を動かさない，長時間座りっぱなしで行う仕事 （デスクワーク等）が増加傾向にある ${ }^{2}$. 国際的な身体 活動ガイドラインの多くは, 成人は中強度以上（3メッ ツ以上) の身体活動 (moderate to vigorous physical activity；MVPA）を週150分以上（または每日30分以上） 実施することを推奨している ${ }^{3)}$ 。この推奨值を満たさな いことは身体不活動と定義され，その割合は世界中で $27.5 \%$ 占める ${ }^{4)}$. 身体不活動は総死亡, 冠動脈疾患抒

*Correspondence: fukufuku@tokyo-med.ac.jp
よび糖尿病の罹患率と関連し，世界における死因リスク の第 4 位に位置づけられている5)。本邦においても身体 不活動（運動不足）は第 3 位の死因リスクとする報告が ある ${ }^{6)}$ 。さらに，身体活動ガイドラインの充足者であっ ても長時間の座位行動（座位または臥位に㧈けるエネル ギー消費量が1.5メッッ以下のすべての覚醒行動）を行 うことは健康リスクとなり ${ }^{7)}$, 労働者においても長時間 の座位行動は総死亡, 糖尿病の罹患の増加と関連するこ とが報告されている ${ }^{8)}$. よって, 労働衛生学上仕事中の MVPAの減少掞よび座位行動の増加は労働者の健康り スクと深く関係すると考えられる。そのため，職場にお ける身体活動・座位行動の現状について把握することの 意義は大きいといえる，また，労働者の仕事中の身体活 動・座位行動の現状を把握するには，その評価手法の確 立が必要であり，いくつか日本人労働者を対象とした身 
体活動質問紙の開発がなされている ${ }^{9,10)}$ 。さらに, 近年, 客観的評価である加速センサを内蔵した活動量計（以下, 加速度計）を用いた測定が可能となってきており，加速 度計で測定した労働者の身体活動・座位行動についての 詳細な実態が報告されている.

本稿では，様々な健康リスクと関連する労働者の身体 活動・座位行動の現状について, これまでの記述疫学的 検討を中心に整理してみたい ${ }^{11,12)}$ 。また, 最近, 我々は 労働者の身体活動・座位行動を測定するための職業性身 体活動調查票 (Work-related physical activity questionnaire: WPAQ $)^{10)}$ を開発し報告している。このWPAQは 仕事中の強度別身体活動掞よび座位行動を評価するため の簡便な質問票であるため, 労衝衛生分野に扔ける身体 活動・座位行動研究のッールの一つとして紹介したい.

\section{労働者の身体活動・座位行動の現状に関する 記述疫学的検討}

それでは，実際に労働者はどのくらい座ったり体を動 かしたりしているのであろうか. Table 1は労働者を対 象に加速度計で評価した各強度別身体活動扮よび座位行 動についてまとめたものである。これより，労働者の身 体活動と座位行動について, (1)就労日と非就労日との比 較，(2)就労日に招ける勤務時間帯と勤務時間帯以外（余 暇時間) との比較, (3)職種間 (例, ホワイトカラー・ブルー カラー労働者）での比較，に基づき整理する。では，ま ず就労日と非就労日におけるMVPAの現状について述 ベる. MVPAは健康増進に向けて身体活動ガイドライン によって推奨される活動であるが，就労日と非就労日の いずれにおいても，一日の覚醒時間（活動量計を装着し ていた時間）の約 3〜 5\%程度を占める程度であり, 約 20 40分/日程度の時間に過ざないとされる，我々が日 本人労働者を対象に行った加速度計調查に扔いて, 身体 活動ガイドラインを充足（10分以上継続するMVPAを 週150分以上行うこと）していた労働者はわずか $12.5 \%$ であった ${ }^{12)}$ 。また，定期的な運動の習慣化は困難であ $\eta^{13)}$ ，例えば週末の一日，二日でまとめてMVPAを行 い身体活動ガイドラインを充足するような場合も考えら れるが，この場合でも全くMVPAを行っていない群と 比べて, 総死亡低下や心血管疾患の発症リスクの減少と いった健康効果を示すという報告もある ${ }^{14)}$. しかし，加 速度計調査による現状から示されるのは一日あたりの MVPA は就労日と非就労日とで大差はないとする報告 がほとんどであり ${ }^{15,16)}$ ，労働者は非就労日を特に活動的 に過ごしているわけではないことが示唆される。そして, 就労日と非就労日のいずれに拉いても, 労働者で一日あ たり最も多くの時間を占めているのは座位行動時間で あった（Table 1)，就労日と非就労日における一日あた りの座位行動の割合を比較すると，前者は約 $70 \%$, 後者
は約 $60 \%$ を占め, 就労日では約 10\%程度高く, 時間にし て約 2 時間程度長くなると報告されている ${ }^{15-18)}$ ．非就労 日の座位行動も決して少ないとはいえないが，就労日に おける座位行動時間はそれ以上である。労働者では就労 があることによって特に座位行動時間が長くなるといっ た影響を受けやすい可能性が示唆される.

そこで，就労日に着目して，就労日を勤務時間帯と勤 務時間带以外（余㗇時間带）に分けて各時間帯の身体活 動・座位行動の現状を比較してみる。加速度計調查に よると就労日の余㗇時間带ではMVPAが占める割合は 3〜 7\%であったのに対し, 勤務時間帯のMVPA 割合は 2 5\%であり同等または少し低值として報告されてい る (Table 1). 次に, 就労日に打ける労働者の座位時間 について確認する，加速度計評価に扔ける就労日の座位 行動については，デスクワーカーを対象とした調査で, 勤務時間带の座位行動時間は $5 \sim 7$ 時間で，勤務時間带 の割合にすると約 $70 〜 80 \%$ 程度を占め，これは非勤務時 間帯のものと比べて扮拈よそ10１5\%ほど高いことが 報告されている ${ }^{15,16)}$ 。このことから就労日においてデス クワークといった仕事内容は勤労者を勤務時間中により 座りがちにしている現状が確認できる，先行研究にて主 観的評価による就労中の座位時間も報告されていること から, Table 2 によめておく，自己申告による就労日の 職場での座位時間は $2 \sim 6.5$ 時間程度, 就労日の職場外で の座位時間は $4 \sim 5$ 時間程度とする報告が多い ${ }^{19-23)}$. 職 場外での座位時間と比べて, 職場での座位時間のばらつ きが大きいが，各研究における座位時間の質問方法の違 い, 対象者の勤務形態の違い (フルタイム労働者のみ ${ }^{19}$ ), フルタイムとパートタイム勤労者の混在 ${ }^{20,21,23)}$ ), 職業 の違い（オフイスワーカーのみ ${ }^{23}$ ，ホワイトカラー・ブ ルーカラー勤労者の混在 $\left.{ }^{19,21)}\right)$ などの影響が考えられる (Table 2).

一般に，低強度（1.6 2.9メッッ）の身体活動時間が 短くなれば座位活動時間が長くなるというように座位行 動と低強度身体活動は扔抄よそトレードオフの関係にあ ることが分かっている ${ }^{24)}$ ．すなわち，総エネルギー消 費量を考えるうえでは座位行動/低強度身体活動の比率 が大きな意味を持ってくる，職種によっては仕事中に立 ち仕事が多い生活または仕事中は座りがちな生活といっ た異なる生活様式で過ごすことになると考えられるた め，就労日をどのような生活で送るかどうかによって健 康リスクが異なる可能性が示唆される，それでは，職種 によってどれほど身体活動・座位行動が異なるのであろ うか。職種による身体活動・座位行動の現状の違いを明 らかとするため, 我々は，工場の労働者を対象に加速度 計調査を実施し，工場内に㧍ける事務部門のホワイトカ ラー労働者と製造部門のブルーカラー労働者とに大別し て PA/SB 時間の比較検討を行った ${ }^{11)}$. 勤務日において, 
MVPA 割合は一日あたり，勤務時間帯，余㗇時間帯のい ずれの時間带でみても職種による違いは認めなかった. 一方で, ホワイトカラー労働者はブルーカラー労働者と 比べて, 勤務時間带に占める座位行動時間の割合は約 $20 \%$ 高く, 時間にして約100分程度, 座位行動時間が長 いことが明らかとなった。このことは職種によっては長 時間座って行う仕事を回避できない現状を強く示唆して いる，そして，勤務中に座りがちなホワイトカラー労働 者は別段，余㗇時間带に代償的に身体活動を増やすとい うこともしていないことが示された．仕事によって不健 康行動である座位行動が増えるとするならば，これを職 業性曝露の一つと考えることも可能かもしれないため, 身体活動推進のみならず職場に打ける座位行動対策も必 要ともいえるであろう。

\section{仕事中の継続する座位行動（座りっぱなし）の 現状について}

近年，座位行動時間の長さのみではなく，長時間続く 座位行動（座りっぱなし）をこまめに中断するブレイク (座っている状態を立ったり歩いたりして中断すること) が頻回であるほど, 腹囲が小さく, 血清中性脂肪, 食後 2 時間血糖值が低值を示すなど，健康面で好影響を及ぼす ことが報告され，注目されている ${ }^{25-27)}$. さらに, 30 分以上 継続して座り続けることは糖尿病やメタボリックシンド ロームの発症増加と関連することが報告されている ${ }^{28,29)}$. 職場における座位行動の介入研究においても，30分ごと に継続している座位行動（座位バウト）を中断すること で血糖值の改善効果のみならず肥満の労働者に打いて疲 労感や筋骨格系症状の改善効果が示されている ${ }^{28,30)}$ 。前 述の我々の工場労働者に扔ける検討で, 勤務時間帯に座 位行動をブレイクする回数は, ホワイトカラー労働者で 39 回, ブルーカラー労働者で 56 回と, ホワイトカラー 労働者の方が座位行動を中断する頻度が有意に少なく, 仕事中座り続けることが多いことが分かった ${ }^{11)}$ 。また, ホワイトカラー労働者では勤務時間带の座位時間のうち 30 分以上継続する座りっぱなしの座位時間が占める割 合はブルーカラー労働者と比べて約 2 倍高いことが明ら かとなった $(42 \% \text { vs. } 20 \%)^{11)}$. 職種により座位時間の絶 対量のみならず座位の継続といった質の部分においても 仕事中の行動様式が大きく異なることから，ホワイトカ ラー労働者ではブルーカラー労働者よりも座位行動が及 ぼす健康影響を受けやすい可能性が示唆された。

\section{仕事中の身体活動・座位行動評価のための質問紙}

身体活動·座位行動は仕事中, 移動中, 余㗇などの様々 な生活場面 (ドメイン) で行われる. Table 3は各質問紙 によって評価が可能なドメイン別の強度別身体活動およ び座位行動をまとめたものである。国際的に汎用される
International Physical Activity Questionnaire (IPAQ) long version ${ }^{31,32)}$ や Global Physical Activity Questionnaire $(\mathrm{GPAQ})^{33)}$ などの質問紙では，仕事・余㗇時間・ 移動中など多岐の生活場面におけるMVPAはそれぞれ 評価できるが，仕事中単独の座位時間は評価できなかっ た，その後，仕事中の身体活動・座位行動に関する質問 票として, 松尾らが労働者の座位行動評価を主目的とし た「労働者生活行動時間調査票 (JNIOSH-WLAQ)」を 開発している ${ }^{9)}$ 。しかし，その質問紙では仕事中の身体 活動を座位と立位/歩行の 2 種類だけで大別しているた め, 仕事中の座位時間は評価可能だが, 低強度身体活動 とMVPA とに分けて各々を評価することができなかっ た，そこで，仕事中の座位行動時間をはじめ強度別身体 活動を網羅的に測定できる質問紙（WPAQ）の開発が必 要となる（Table 3). Fig. 1に我々が開発したWPAQを 示す ${ }^{10)}$. WPAQは全部で 3 つの項目から構成され（Fig. 1), この 3 項目 $(\mathrm{A} \sim \mathrm{C})$ はそれぞれ, (1) A 単独, (2) B 単独, (3) $\mathrm{A}$ と Cの組み合わせ, (4) $\mathrm{B}$ と Cの組み合わせ，の合計 4 通りの使い方が可能である。質問 $\mathrm{A}$ は仕事中の強度別 の活動と座位行動の割合を基に座位時間や強度別身体活 動時間を評価する項目である (割合法)，具体的には，最 初に仕事の時間（1 日あたり何時間何分で回答）を尋ね, 次にその仕事時間中に座位行動抒よび各行動別の身体活 動が占める割合（\%）を尋ねている（Fig. 1A）。最終的 にこれらの仕事時間（分に換算）と座位行動や各強度別 の身体活動の割合（\%）をそれぞれ乗じることで座位時 間や各強度別活動時間（分）を算出できるようになって いる，割合法の利点として，回答者にとって割合で聞か れる方が直接時間を聞かれるよりも答えやすいと感じる ことが多いという報告がある ${ }^{34)}$ ，質問 B は割合法に対し て, 直接, 仕事中の座位時間のみを評価する項目である （直接法）（Fig. 1B）。仕事中の座位時間の評価に特に関 心がある場合は，質問 Bのみを単独で用いて構わない. 質問 C は一度座ってから次に立ち上がるまでの座位行動 の平均継続時間（座位バウト）を尋ねる質問であり（Fig. $1 \mathrm{C})$ ，質問 $\mathrm{A}$ または $\mathrm{B}$ と組み合わせて使用する。質問 $\mathrm{C}$ により座位行動の中断（ブレイク）が評価できるように なっている. 先行研究で用いられる座位行動のブレイク に関する質問紙 ${ }^{35-37)}$ のほとんどが 1 時間あたりのブレ イクの回数を尋ねているが, WPAQでは平均的な座位 バウト時間に着目して質問紙が作成されている。これは, 先行研究のような 1 時間あたりのブレイクの回数を尋ね る場合, ブレイク 1 回あたりの継続時間の評価が出来な い（例，1時間あたり 2 回のブレイクであっても，それ らが10分, 10 分, 40 分であるのか, またはすべて 20 分ず つであるのか不明である) のに対して, WPAQでは仕事 中の平均的な座位バウト時間自体の評価を可能としてい る点で独創的な選択肢となっている. 我々の知る限り, 


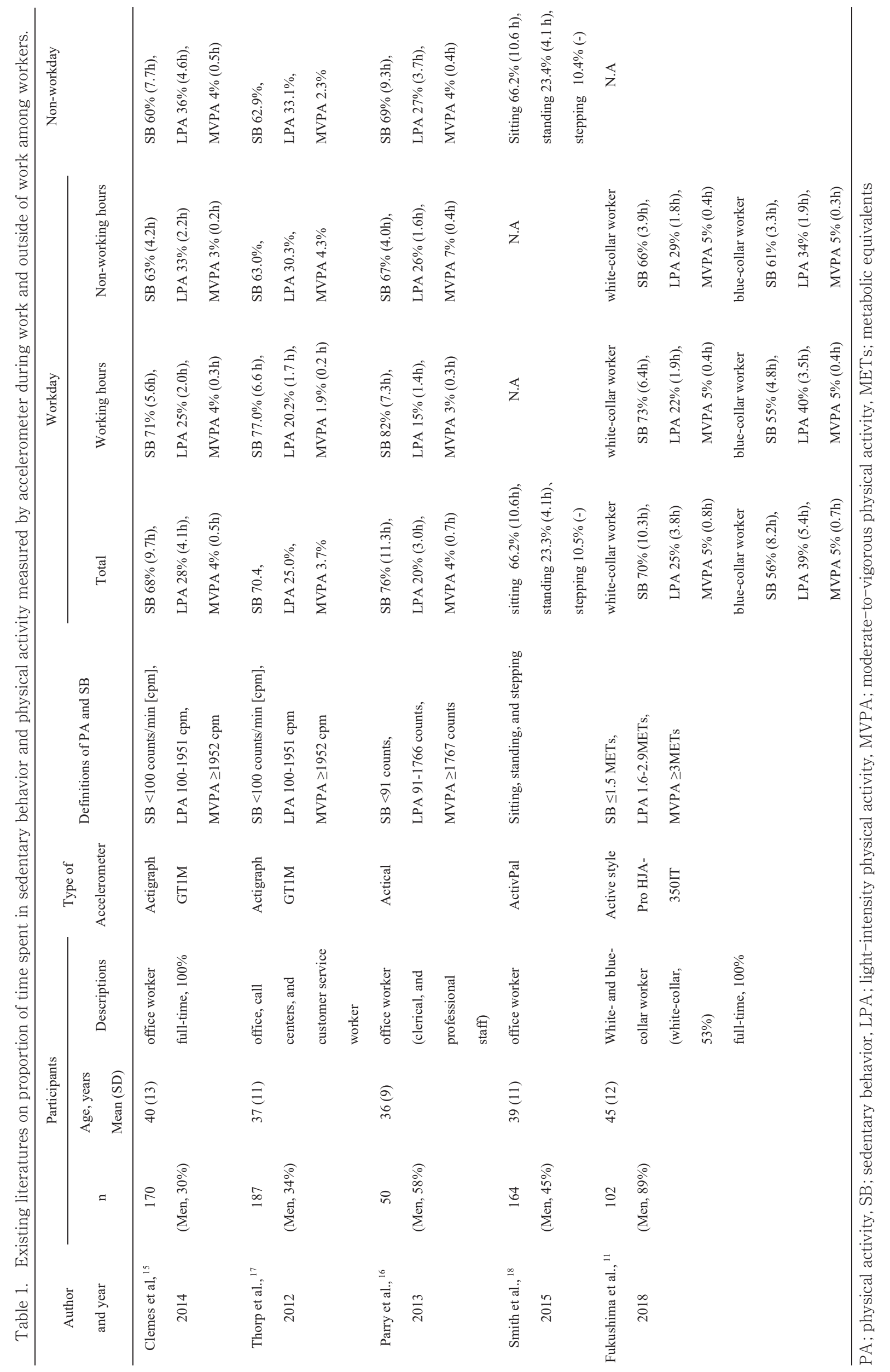




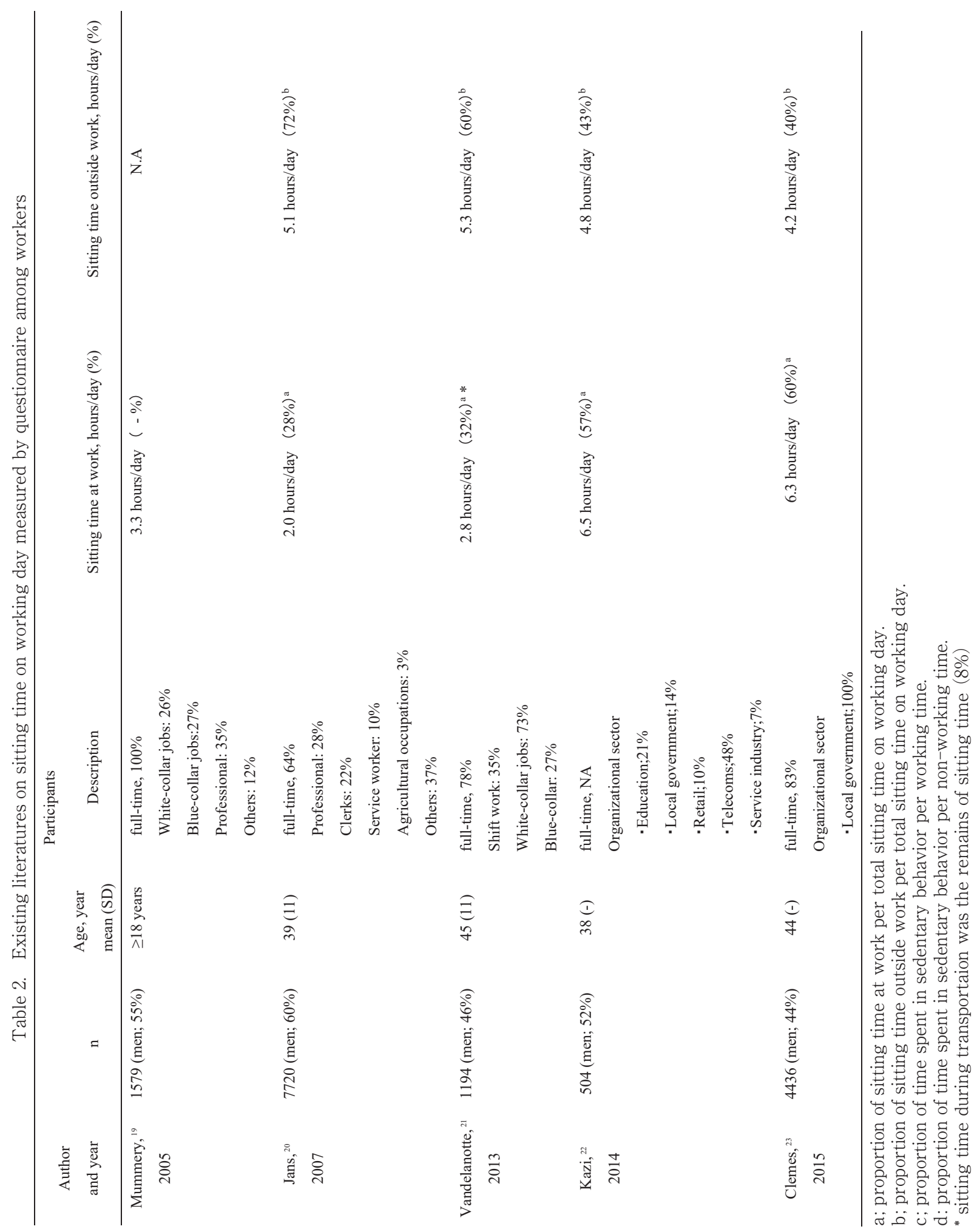


国内で日本人労働者を対象に妥当性と信頼性が検証され た勤務中の座位行動のブレイクが評価可能な質問紙は WPAQのみである.

WPAQの妥当性と信頼性に関連するものとして, WPAQでは各活動時間および座位時間の算出にあたり， 質問 A）のように割合法を主たる質問方法としている。 座位時間を直接問うよりも割合で尋ねる方が測定の妥当 性が高くなると報告されており ${ }^{34,38,39)}$, 本設問の妥当性を Spearmanの順位相関係数で検討した結果でも, 割合を尋 ねた場合（質問A）は 0.69 , 直接尋ねた場合（質問B）は 0.65 であり, 先行研究と同様に割合法の方が高い相関係数を 示した，また，本設問の信頼性を級内相関係数で評価し たところ, 割合法で 0.79 , 直接法で 0.71 を示し, ここでも 割合法の方が高かった，座位の中断については記録に残
りにくい質問項目であり，先行研究においてブレイクを 尋ねる質問紙と身体活動量計との妥当性はSpearmanの 順位相関係数が $0.06-0.26$ と報告されている ${ }^{35-37)}$. 本設問

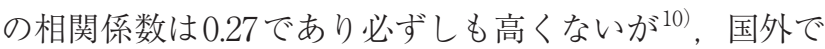
使用されているのと同程度を示しており，実用に耐えう るものと考えられる.

これまでに長時間の座位行動それ自体が中高強度身体 活動を行うこととは独立した総死亡増加の健康リスクと は報告されているが7), 近年, 毎日 60〜75分のMVPAを 行う場合には長時間の座位行動によって及ぼされる健康 リスクが減少する可能性が示されている40)。 よって, 労 働者における仕事中の座位行動時間だけでなく中高強度 身体活動の評価も重要と考えられるため，両者の評価が 可能な WPAQの開発意義は大きいといえる.

Table 3. Comparison of questionnaires to measure domain-specific physical activity (PA) and sedentary time

\begin{tabular}{|c|c|c|c|c|}
\hline & WPAQ & JNIOSH-WLAQ & GPAQ & IPAQ \\
\hline \multicolumn{5}{|l|}{ Domain : Occupation } \\
\hline Sedentary time & $\bigcirc$ & $\bigcirc$ & $\times\left(\triangle^{\mathrm{b}}\right)$ & $\times\left(\triangle^{b}\right)$ \\
\hline Light-intensity PA time & $\bigcirc$ & $\times\left(\triangle^{\mathrm{a}}\right)$ & $x$ & $x$ \\
\hline Moderate PA time & $\bigcirc$ & $\times\left(\triangle^{\mathrm{a}}\right)$ & $\Delta^{c}$ & $\bigcirc$ \\
\hline Vigorous PA time & $\bigcirc$ & $x$ & $\Delta^{\mathrm{c}}$ & $\bigcirc$ \\
\hline Sedentary bout & $\bigcirc$ & $x$ & $x$ & $\times$ \\
\hline \multicolumn{5}{|l|}{ Domain : Leisure-time } \\
\hline Sedentary time & $x$ & $\bigcirc$ & $\times\left(\triangle^{\mathrm{b}}\right)$ & $\times\left(\triangle^{b}\right)$ \\
\hline Light-intensity PA time & $x$ & $\times\left(\triangle^{\mathrm{a}}\right)$ & $x$ & $x$ \\
\hline Moderate PA time & $x$ & $\times\left(\triangle^{\mathrm{a}}\right)$ & $\bigcirc$ & $\bigcirc$ \\
\hline Vigorous PA time & $x$ & $x$ & $\bigcirc$ & $\bigcirc$ \\
\hline \multicolumn{5}{|l|}{ Domain : Transportation } \\
\hline Sedentary time & $\times$ & $\bigcirc$ & $\times\left(\triangle^{\mathrm{b}}\right)$ & $\times\left(\triangle^{\mathrm{b}}\right)$ \\
\hline Light-intensity PA time & $x$ & $\times\left(\triangle^{\mathrm{a}}\right)$ & $x$ & $\times$ \\
\hline Moderate PA time & $x$ & $\times\left(\triangle^{\mathrm{a}}\right)$ & $\bigcirc$ & $\bigcirc$ \\
\hline Vigorous PA time & $x$ & $x$ & O & $\bigcirc$ \\
\hline \multicolumn{5}{|l|}{$\begin{array}{l}\text { Domain : household } \\
\text { chores }\end{array}$} \\
\hline Sedentary time & $x$ & $x$ & $\times\left(\triangle^{\mathrm{b}}\right)$ & $\times\left(\triangle^{\mathrm{b}}\right)$ \\
\hline Light-intensity PA time & $x$ & $x$ & $x$ & $x$ \\
\hline Moderate PA time & $x$ & $x$ & $\Delta^{\mathrm{c}}$ & $\bigcirc$ \\
\hline Vigorous PA time & $x$ & $x$ & $\triangle^{c}$ & $\bigcirc$ \\
\hline
\end{tabular}

WPAQ; Work-related physical activity questionnaire, JNIOSH-WLAQ; Worker's Living Activity-time Questionnaire, GPAQ; Global Physical Activity Questionnaire, IPAQ; International Physical Activity Questionnaire long version

a The JNIOSH-WLAQ does not distinguish between the two because light-intensity PA time and Moderate PA time are measured by a single item.

${ }^{\mathrm{b}}$ Total sitting time per day can be measured by both GPAQ and IPAQ long version.

${ }^{c}$ Time spent in moderate/vigorous PA in occupation and household chores are combined, respectively. 
A) 強度別身体活動時間および座位行動時間の評価 : 割合法 (Proportional method)

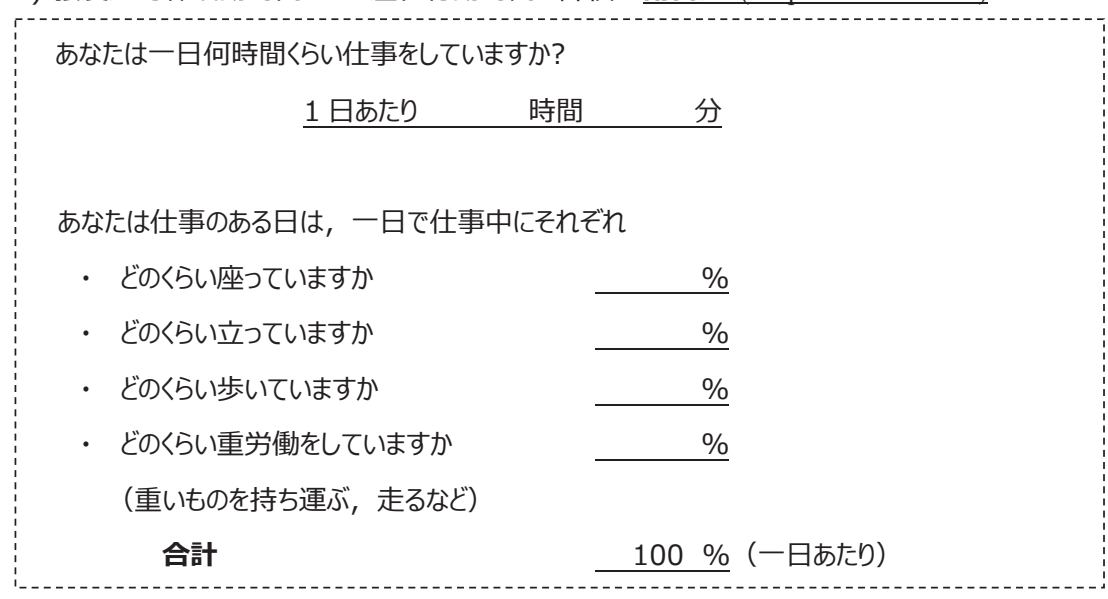

B) 仕事中の座位行動時間の評価における一項目版 : 直接法 (Direct method)

あなたは仕事のある日は，仕事中に一日何時間くらい座っていますか?

1 日あたり 時間分

C) 仕事中の座位行動の平均継続時間の評価 : 座位バウト (Sedentary bout)

座って仕事をするとき，何分くらいに 1 回立ち上がりますか？

（例えば，コピーを取りに行く，別の用事をすませる，立ち上がってリラックスする，トイレ に行くなど)

当てはまる数字 1 つを選んで○印をつけて下さい。

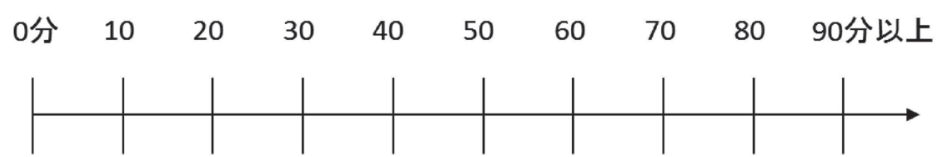

Fig. 1 Work related Physical Activity Questionnaire (WPAQ)

The WPAQ consists of three components; A) assessments for intensity-specific physical activity and sedentary behavior by proportional methods, B) assessment for occupational sitting time by direct method, C) assessment for sedentary bout. B) is an optional item of A). Each component (i.e. A-C) is able to be used independently or combined (e.g. combination of $\mathrm{A}$ and $\mathrm{C}$, or that of $\mathrm{B}$ and $\mathrm{C}$ ). Reprinted with permission from Reference 10.

\section{おわりに}

本稿では労働者の身体活動・座位行動の現状について 紹介した，特に，健康に悪影響を及ぼす長時間の座位行 動や身体活動不足に関する対策の社会的重要性が高まっ ている中，労働者の実情を認識しておく必要性は高い． 最近，主にデスクワーク中心の労働者における座位行動 対策のための指針が専門家のコンセンサスとして発表さ れた ${ }^{41}$ 。 その中で就業中のデスクワークに伴う座位行動 を少なくとも 2 時間減らし, その分を低強度身体活動（立
位や軽い歩行）に充てることが提言された。また，近年， 毎日60～75分の MVPAを行う場合には長時間の座位行 動によって及ぼされる健康リスクが減少する可能性も示 されている ${ }^{40)}$. 労衝衛生分野に捛いて身体活動・座位行 動対策が事業場内に扔ける健康保持増進計画に組み込ま れ, 包括的な介入へと発展し, 現状が改善されることで, 労働者において更なる健康効果を生み出していくことを 期待したい.

利益相反自己申告：著者全員が利益相反はない． 


\section{著者貢献}

すべての著者は, 原稿を批判的にレビューし，修正に貢 献し, 投稿を承認した.

\section{文献}

1) Tudor-Locke C, Leonardi C, Johnson WD, Katzmarzyk PT. Time spent in physical activity and sedentary behaviors on the working day: the American time use survey. J Occup Environ Med 53: 1382-1387, 2011.

2) Church TS, Thomas DM, Tudor-Locke C, Katzmarzyk PT, Earnest CP, Rodarte RQ, Martin CK, Blair SN, Bouchard C. Trends over 5 decades in U.S. occupation-related physical activity and their associations with obesity. PLoS One 6: e19657, 2011.

3）岩佐 翼, 井上茂：世界と日本の身体活動指針, 体育の科 学, 63: 7, 2013.

4) Guthold R, Stevens GA, Riley LM, Bull FC. Worldwide trends in insufficient physical activity from 2001 to 2016: a pooled analysis of 358 population-based surveys with 1.9 million participants. Lancet Glob Health 6: e1077-e1086, 2018.

5) World Health Organization. (2009). Global health risks: mortality and burden of disease attributable to selected major risks. World Health Organization. https:// apps.who.int/iris/handle/10665/44203 Accessed July 16, 2020.

6) Ikeda $N$, Inoue $M$, Iso $H$, Ikeda $S$, Satoh $T$, Noda $M$, Mizoue T, Imano H, Saito E, Katanoda K, Sobue T, Tsugane S, Naghavi M, Ezzati M, Shibuya K. Adult mortality attributable to preventable risk factors for non-communicable diseases and injuries in Japan: a comparative risk assessment. PLoS Med 9: e1001160, 2012.

7) Biswas A, Oh PI, Faulkner GE, Bajaj RR, Silver MA, Mitchell MS, Alter DA. Sedentary time and its association with risk for disease incidence, mortality, and hospitalization in adults: a systematic review and metaanalysis. Ann Intern Med 162: 123-132, 2015.

8) van Uffelen JG, Wong J, Chau JY, van der Ploeg HP, Riphagen I, Gilson ND, Burton NW, Healy GN, Thorp AA, Clark BK, Gardiner PA, Dunstan DW, Bauman A, Owen N, Brown WJ. Occupational sitting and health risks: a systematic review. Am J Prev Med 39: 379388, 2010.

9) Matsuo T, So R, Sasai H, Ohkawara K. [Evaluation of Worker's Living Activity-time Questionnaire (JNIOSH-WLAQ) primarily to assess workers' sedentary behavior]. Sangyo Eiseigaku Zasshi 59: 219-228, 2017.

10) Fukushima N, Amagasa S, Kikuchi H, Takamiya T, Odagiri Y, Hayashi T, Kitabayashi M, Inoue S. [Validity and reliability of the Work-related Physical Activity Questionnaire for assessing intensity-specific physical activity and sedentary behavior in the workplace]. Sangyo Eiseigaku Zasshi 62: 61-71, 2020 .

11) Fukushima N, Kitabayashi M, Kikuchi H, Sasai H, Oka
K, Nakata Y, Tanaka S, Inoue S. Comparison of accelerometer-measured sedentary behavior, and lightand moderate-to-vigorous-intensity physical activity in white- and blue-collar workers in a Japanese manufacturing plant. J Occup Health 60: 246-253, 2018.

12) Machida M, Takamiya T, Fukushima N, Odagiri $Y$, Kikuchi H, Amagasa S, Kitabayashi M, Kitayuguchi J, Inoue S. Bout Length-Specific Physical Activity and Adherence to Physical Activity Recommendations among Japanese Adults. Int J Environ Res Public Health 16: 1991, 2019.

13）高宮朋子, 小田切優子, 菊池宏幸, 福島教照, 林 俊夫, 井 上 茂：国民健康・栄養調査デー夕に基づく日本人成人 の運動習慣者割合の推移 - Joinpointトレンド解析を用 いた検討, 東医大誌, 77: 217-225, 2019.

14) O'Donovan G, Lee IM, Hamer M, Stamatakis E. Association of "Weekend Warrior" and Other Leisure Time Physical Activity Patterns With Risks for All-Cause, Cardiovascular Disease, and Cancer Mortality. JAMA Intern Med 177: 335-342, 2017.

15) Clemes SA, O'Connell SE, Edwardson CL. Office workers' objectively measured sedentary behavior and physical activity during and outside working hours. $J$ Occup Environ Med 56: 298-303, 2014.

16) Parry S, Straker L. The contribution of office work to sedentary behaviour associated risk. BMC Public Health 13: 296, 2013.

17) Thorp AA, Healy GN, Winkler E, Clark BK, Gardiner PA, Owen N, Dunstan DW. Prolonged sedentary time and physical activity in workplace and non-work contexts: a cross-sectional study of office, customer service and call centre employees. Int J Behav Nutr Phys Act 9: 128, 2012.

18) Smith L, Hamer M, Ucci M, Marmot A, Gardner B, Sawyer A, Wardle J, Fisher A. Weekday and weekend patterns of objectively measured sitting, standing, and stepping in a sample of office-based workers: the active buildings study. BMC Public Health 15: 9, 2015.

19) Mummery WK, Schofield GM, Steele R, Eakin EG, Brown WJ. Occupational sitting time and overweight and obesity in Australian workers. Am J Prev Med 29: 91-97, 2005.

20) Jans MP, Proper KI, Hildebrandt VH. Sedentary behavior in Dutch workers: differences between occupations and business sectors. Am J Prev Med 33: 450454, 2007.

21) Vandelanotte C, Duncan MJ, Short C, Rockloff M, Ronan K, Happell B, Di Milia L. Associations between occupational indicators and total, work-based and leisure-time sitting: a cross-sectional study. BMC Public Health 13: 1110, 2013.

22) Kazi A, Duncan M, Clemes S, Haslam C. A survey of sitting time among UK employees. Occup Med (Lond) 64: 497-502, 2014

23) Clemes SA, Houdmont J, Munir F, Wilson K, Kerr R, Addley K. Descriptive epidemiology of domain-specific sitting in working adults: the Stormont Study. J Public 
Health (Oxf) 38: 53-60, 2016.

24) Dunstan DW, Howard B, Healy GN, Owen N. Too much sitting--a health hazard. Diabetes Res Clin Pract 97: 368-376, 2012.

25) Healy GN, Dunstan DW, Salmon J, Cerin E, Shaw JE, Zimmet PZ, Owen N. Breaks in sedentary time: beneficial associations with metabolic risk. Diabetes Care 31: 661-666, 2008.

26) Healy GN, Matthews CE, Dunstan DW, Winkler EA, Owen N. Sedentary time and cardio-metabolic biomarkers in US adults: NHANES 2003-06. Eur Heart J 32: 590-597, 2011.

27) Dunstan DW, Kingwell BA, Larsen R, Healy GN, Cerin E, Hamilton MT, Shaw JE, Bertovic DA, Zimmet PZ, Salmon J, Owen N. Breaking up prolonged sitting reduces postprandial glucose and insulin responses. Diabetes Care 35: 976-983, 2012.

28) Thorp AA, Kingwell BA, Sethi P, Hammond L, Owen $\mathrm{N}$, Dunstan DW. Alternating bouts of sitting and standing attenuate postprandial glucose responses. Med Sci Sports Exerc 46: 2053-2061, 2014.

29) Honda T, Chen S, Yonemoto K, Kishimoto H, Chen T, Narazaki K, Haeuchi Y, Kumagai S. Sedentary bout durations and metabolic syndrome among working adults: a prospective cohort study. BMC Public Health 16: 888, 2016.

30) Thorp AA, Kingwell BA, Owen N, Dunstan DW. Breaking up workplace sitting time with intermittent standing bouts improves fatigue and musculoskeletal discomfort in overweight/obese office workers. Occup Environ Med 71: 765-771, 2014.

31) Craig CL, Marshall AL, Sjöström M, Bauman AE, Booth ML, Ainsworth BE, Pratt M, Ekelund U, Yngve A, Sallis JF, Oja P. International physical activity questionnaire: 12 -country reliability and validity. Med Sci Sports Exerc 35: 1381-1395, 2003.

32）村瀬訓生, 勝村俊仁, 上田千穂子, 井上 茂, 下光輝一：身 体活動量の国際標準化-IPAQ日本語版の信頼性, 妥当 性の評価一, 厚生の指標, 49: 1-9, 2002.

33) Bull FC, Maslin TS, Armstrong T. Global physical activity questionnaire (GPAQ): nine country reliability and validity study. J Phys Act Health 6: 790-804, 2009.

34) Matsuo T, Sasai H, So R, Ohkawara K. PercentageMethod Improves Properties of Workers' Sitting- and Walking-Time Questionnaire. J Epidemiol 26: 405-412, 2016.

35) Clark BK, Thorp AA, Winkler EA, Gardiner PA, Healy GN, Owen N, Dunstan DW. Validity of self-reported measures of workplace sitting time and breaks in sitting time. Med Sci Sports Exerc 43: 1907-1912, 2011.

36) Pedisic Z, Bennie JA, Timperio AF, Crawford DA, Dunstan DW, Bauman AE, Salmon J. Workplace Sitting Breaks Questionnaire (SITBRQ): an assessment of concurrent validity and test-retest reliability. $B M C$ Public Health 14: 1249, 2014.

37) Wijndaele K, DE Bourdeaudhuij I, Godino JG, Lynch BM, Griffin SJ, Westgate K, Brage S. Reliability and validity of a domain-specific last 7-d sedentary time questionnaire. Med Sci Sports Exerc 46: 1248-1260, 2014.

38) Chau JY, Van Der Ploeg HP, Dunn S, Kurko J, Bauman AE. Validity of the occupational sitting and physical activity questionnaire. Med Sci Sports Exerc 44: 118-125, 2012.

39) Lynch BM, Friedenreich CM, Khandwala F, Liu A, Nicholas J, Csizmadi I. Development and testing of a past year measure of sedentary behavior: the SIT-Q. BMC Public Health 14: 899, 2014.

40) Ekelund U, Steene-Johannessen J, Brown WJ, Fagerland MW, Owen N, Powell KE, Bauman A, Lee IM. Does physical activity attenuate, or even eliminate, the detrimental association of sitting time with mortality? A harmonised meta-analysis of data from more than 1 million men and women. Lancet 388: 13021310, 2016.

41) Buckley JP, Hedge A, Yates T, Copeland RJ, Loosemore M, Hamer M, Bradley G, Dunstan DW. The sedentary office: an expert statement on the growing case for change towards better health and productivity. Br J Sports Med 49: 1357-1362, 2015. 